\title{
Role of Renal Prostaglandins in Sympathetically Mediated Renin Release in the Rat
}

\author{
William B. Campbell, Robert M. Graham, and Edwin K. Jackson, University \\ of Texas Health Science Center, Department of Pharmacology, Division of Clinical \\ Pharmacology, Dallas, Texas 75235
}

A B S T R A C T Renal prostaglandins (PG) appear to mediate renin release due to stimulation of the intrarenal baroreceptor, but not that due to activation of the macula densa. However, as the role of PG in sympathetically mediated renin release remains unclear, a possible interrelationship between these factors was examined in conscious rats. Hydralazine increased the serum renin levels from $3.1 \pm 0.8$ to $16.7 \pm 3.0 \mathrm{ng} / \mathrm{ml}$ per $\mathrm{h}$ at a dose of $1 \mathrm{mg} / \mathrm{kg}$. Indomethacin $(5 \mathrm{mg} / \mathrm{kg}) \mathrm{sup}$ pressed urinary $\mathrm{PGE}_{2}$ and $\mathrm{PGF}_{2 \alpha}$ excretion by 89 and $74 \%$, respectively, arachidonate hypotension by $82 \%$, and inhibited the elevated renin levels from hydralazine by $100 \%$ without altering the hypotensive effect of the drug. Another PG synthetase inhibitor, meclofenamate, was also effective in attenuating hydralazineinduced renin release, urinary $\mathrm{PGE}_{2}$ and $\mathrm{PGF}_{2 \alpha}$ excretion, and arachidonate hypotension. Isoproterenol, a nonselective beta-adrenergic agonist, increased heart rate, lowered blood pressure, and also stimulated the release of renin when administered intraperitoneally. However, intrarenal infusion of the drug only resulted in increased renin release. Indomethacin inhibited isoproterenol-induced renin release by 66 and $67 \%$, respectively, without altering the hemodynamic effects associated with the intraperitoneal administration of the drug. The selective beta 1 agonist, H133/22, increased the release of renin and heart rate in a doserelated manner without altering blood pressure. $\mathrm{H133}$ / 22 -induced renin release was inhibited by $80 \%$ by indomethacin pretreatment. Finally, intrarenal infusions of dibutyryl cyclic AMP (3 $\mathrm{mg} / \mathrm{kg}$ per min) increased the serum activity from $4.1 \pm 0.2$ to $20.4 \pm 3.9 \mathrm{ng} / \mathrm{ml}$ per $\mathrm{h}$ without altering mean arterial pressure. Indomethacin inhibited this renin response to dibutyryl cyclic

This work was performed while Dr. Graham was a recipient of the Pharmaceutical Manufacturers Association Inc. Faculty Development award and Dr. Jackson was a National Institutes of Health Predoctorial Fellow (NIGMS GM07062).

Received for publication 12 June 1978 and in revised form 23 April 1979.
AMP by $96 \%$. Thus, renal PG appear to be important mediators of sympathetically stimulated renin release acting as a site distal to the beta-adrenergic receptor.

\section{INTRODUCTION}

The renin-angiotensin system is involved in the homeostatic regulation of arterial blood pressure as well as the maintenance of the elevated blood pressure in several forms of hypertension. Recently, prostaglandins have been implicated as important mediators of the release of renin from the kidney thereby controlling the activity of this system. This conclusion is based on direct evidence obtained from the administration of the prostaglandin precursor, arachidonic acid, or the various prostaglandins themselves, as well as indirect evidence with prostaglandin synthesis inhibitors. Arachidonic acid increases the rate of renin secretion when infused into the renal artery of experimental animals (1-3) and when added to the incubation media of renal cortical slices $(4,5)$. Because this effect on renin release can be blocked in vivo and in vitro by indomethacin, an inhibitor of prostaglandin synthesis (6), arachidonic acid must be converted to one of its prostaglandin $(P G)^{1}$ intermediates to exert its action $(1,4,5)$. In similar studies, intrarenal infusions of $\mathrm{PGE}_{1}$ and $\mathrm{PGE}_{2}(7-$ 11), $\mathrm{PGD}_{2}(9,10), \mathrm{PGI}_{2}(11)$, and intravenous infusions of $\operatorname{PGA}_{1}(12,13)$ also stimulated the release of renin; however, only the $\mathrm{PG}$ endoperoxides, $\mathrm{PGG}_{2}$ and $\mathrm{PGH}_{2}$, or $\mathrm{PGI}_{2}$ could increase the rate at which renin was secreted in vitro from renal cortical slices $(4,5)$. Because the endoperoxides can be converted to $\mathrm{PGI}_{2}$ in the renal cortex $(14,15), \mathrm{PGI}_{2}$ would appear to exert a direct action on juxtaglomerular cells, and from the available evidence, would appear to be the arachidonic acid intermediate regulating the release of renin.

Additionally, drugs which block the synthesis of PG

${ }^{1}$ Abbreviations used in this paper: dibutyryl cyclic AMP, $\mathrm{N}^{6}, \mathrm{O}^{2 \prime}$-dibutyryl adenosine, $3^{\prime}: 5^{\prime}$-cyclic monophosphoric acid; PG, prostaglandin(s). 
will inhibit the release of renin. Indomethacin, for example, will inhibit supine plasma renin levels (16-18) as well as those stimulated by upright posture (16) and furosemide $(17,18)$. It will also reduce the hyperreninemia associated with hemorrhage (19), Bartter's syndrome $(20,21)$, acute renal failure $(22)$, and renal hypertension (23). Because the sympathetic nervous system is thought to mediate the elevated renin release associated with some of these aforementioned examples and because the beta-adrenergic blocker, propranolol, can also mitigate the renin release in those same examples (24-26), the contribution of the renal PG to sympathetically mediated renin release was investigated. In our studies, sympathetically mediated renin release was examined in three ways. First, reflex activation of the sympathetic nervous system was produced by the vasodilator, hydralazine $(27,28)$. Secondly, beta-adrenergic receptors were directly stimulated by the nonselective beta agonist, isoproterenol $(5,29,30)$, and the beta ${ }_{1}$ selective agonist, H133/22 (31). Finally, renin release was stimulated distal to the beta-adrenergic receptor by $\mathrm{N}^{6}, \mathrm{O}^{21}$-dibutyryl adenosine, $3^{\prime}: 5^{\prime}$-cyclic monophosphoric acid (dibutyryl cyclic AMP) $(32,33)$. In addition, because hydralazine and isoproterenol have the potential to stimulate renin release by decreasing the blood pressure as well as by stimulating juxtaglomerular cell beta-adrenergic receptors, their effects on renin release and blood pressure were compared with those of chlorisondamine, a ganglionic blocking agent, that stimulates renin release by decreasing the blood pressure without increasing sympathetic nerve activity (34). In these studies, inhibitors of PG synthesis were found to inhibit all three forms of sympathetically mediated renin release tested.

\section{METHODS}

Male Sprague-Dawley rats $(250-300 \mathrm{~g})$ were used in these studies (Simonsen Labs, San Francisco, Calif.). The rats were maintained on a standard Purina rat chow (Ralston Purina Co., St. Louis, Mo.) diet containing $150 \mathrm{meq} \mathrm{Na} / \mathrm{kg}$ and 220 meq $\mathrm{K} / \mathrm{kg}$ and tap water ad libitum. All experiments were performed between 0900 and 1200 on conscious rats to eliminate the influence of diurnal variation, surgical stress, or anesthetic stress on renin release.

In the studies involving renin release, olive oil or a suspension of a PG synthesis inhibitor (indomethacin or meclofenamate, $5 \mathrm{mg} / \mathrm{kg}$ ) in olive oil was injected subcutaneously at time zero. $90 \mathrm{~min}$ later saline, hydralazine, isoproterenol, H133/22, or chlorisondamine was administered intraperitoneally, or subcutaneously as in the case of the latter compound, and the animals were sacrificed at $110 \mathrm{~min}$. The animals were killed by decapitation, and aortic blood was collected in siliconized tubes kept on ice $(27,28)$. The blood samples were allowed to clot at $4^{\circ} \mathrm{C}$, centrifuged at $4^{\circ} \mathrm{C}$, and the serum separated at $4^{\circ} \mathrm{C}$ and stored at $-20^{\circ} \mathrm{C}$ until assayed for serum renin activity.

In the studies involving isoproterenol and dibutyryl cyclic AMP, chronic Weeks' catheters were surgically placed in the abdominal aorta with the tip of the catheter extending above the bifurcation of the renal arteries (35). After a 2-d recovery period, the protocol followed was similar to that previously described with oil or indomethacin administered at time zero followed in $90 \mathrm{~min}$ by a saline, isoproterenol $(100 \mathrm{ng} / \mathrm{kg}$ per $\mathrm{min}$ ), or dibutyryl cyclic AMP (3 mg/kg per min) intraarterial infusion at $50 \mu \mathrm{l} / \mathrm{min}$ for $20 \mathrm{~min}$. After the infusion, the animals were decapitated, and the blood was collected as previously described. Additionally, the trunks of the animals were retained, and the surgical placement of the catheter was verified.

In the studies in which changes in mean arterial blood pressure and heart rate were measured, chronic Weeks' catheters were placed in the abdominal aorta (35). After allowing 2-5 d for the animals to recover from the surgical stress, the conscious rats were placed in individual, closed cages in a quiet room while mean arterial pressure and heart rate were monitored with a Narco RP-1500 pressure transducer (Narco Scientific Industries, Inc., Fort Washington, $\mathrm{Pa}$.) and recorded by a Grass model 7 polygraph (Grass Instrument Co., Quincy, Mass.). After allowing $1 \mathrm{~h}$ for the animals to equilibrate, a protocol identical to those described above was followed. In some animals, sodium arachidonate $(8 \mathrm{mg} / \mathrm{kg})$ was administered intravenously before and $110 \mathrm{~min}$ after pretreatment with a PG synthesis inhibitor, and changes in mean arterial pressure were monitored.

An additional group of 12 rats was placed in metabolism cages to allow the collection of urine. After $2 \mathrm{~d}$ of equilibration, urine was collected for $8 \mathrm{~h}$ from 0900 to 1700 from rats injected with either olive oil or a PG synthesis inhibitor. The urine was then measured, filtered, and stored frozen at $-20^{\circ} \mathrm{C}$ until assayed for PG.

Serum renin activity was measured by the antibody trapping method of Poulsen and Jorgensen (36), and the results were expressed as nanograms of angiotensin I generated at $37^{\circ} \mathrm{C}$ per milliliter of serum per hour (ng angiotensin $\mathrm{I} / \mathrm{ml}$ per $\mathrm{h}$ ). Urinary PG were measured according to the method of Dray et al. (37) involving acid-lipid extraction, silicic acid chromatography, and the radioimmunoassay of $\mathrm{PGE}_{2}$ and $\mathrm{PGF}_{2 \alpha}$. The $\mathrm{PGE}_{2}$ antibody cross-reacted $14 \%$ with $\mathrm{PGE}_{1}$, but $<0.5 \%$ with $\mathrm{PGA}_{2}, \mathrm{PGB}_{2}, \mathrm{PGD}_{2}, 6$-keto $\mathrm{PGF}_{1 \alpha}, \mathrm{PGF}_{2 \alpha}$, or its 15-keto metabolites. The $\mathrm{PGF}_{2 \alpha}$ antibody cross-reacted $100 \%$ with $\mathrm{PGF}_{1 \alpha}$, but $<0.5 \%$ with $\mathrm{PGA}_{2}, \mathrm{PGB}_{2}, \mathrm{PGD}_{2}, 6$-keto $\mathrm{PGF}_{1 \alpha}, \mathrm{PGE}_{2}$, or its 15-keto metabolites. The sensitivity of the assays was $<5 \mathrm{pg} /$ $0.3 \mathrm{ml}$.

The drugs and their sources of supply were as follows: isoproterenol (Sigma Chemical Co., St. Louis, Mo.), dibutyryl cyclic AMP (Sigma Chemical Co.), H133/22 (A. B. Hassle, Mölndal, Sweden), meclofenamate(Parke-Davis), hydralazine (Ciba-Geigy Corp., Summit, N. J.), arachidonic acid (Sigma Chemical Co.), chlorisondamine (Ciba-Geigy Corp.), indomethacin (Sigma Chemical Co.), $\mathrm{PGE}_{2}$ and $\mathrm{PGF}_{2 \alpha}$ (The Upjohn Co., Kalamazoo, Mich.), angiotensin I (Beckman Instruments Inc., Fullerton, Calif.), carrier free ${ }^{125} \mathrm{I}$ (New England Nuclear, Boston, Mass.), and $\left[{ }^{3} \mathrm{H}\right] \mathrm{PGE}_{2}$ and $\left[{ }^{3} \mathrm{H}\right] \mathrm{PGF}_{2 \alpha}$ (New England Nuclear).

Statistical analyses were performed with an unpaired Student's $t$ test for single comparisons and analysis of variance for multiple comparisons.

\section{RESULTS}

Hydralazine caused an increase in serum renin activity (Table I), which had been found previously to result from reflex activation of the sympathetic nervous system $(27,28)$. Indomethacin reduced the control renin levels by $32 \%(P>0.1, \mathrm{NS})$ from $3.1 \pm 0.8$ to $2.13 \pm 0.2 \mathrm{ng} / \mathrm{ml}$ per $\mathrm{h}$. Additionally, hydralazine-in- 
TABLE I

Effect of PG Synthetase Inhibition on Hydralazine and Chlorisondamine-Induced Changes in Renin Release, Mean Arterial Pressure, and Heart Rate in Conscious Rats

\begin{tabular}{lccc}
\hline \multicolumn{1}{c}{ Treatment } & SRA & MAP & HR \\
\hline & $n g$ AI/ml/h & $m m ~ H g$ & beats/min \\
Saline & $3.1 \pm 0.8$ & $108 \pm 3$ & $400 \pm 18$ \\
Indomethacin, 5 mg/kg s.c. & $2.1 \pm 0.1$ & $107 \pm 3$ & $393 \pm 10$ \\
Meclofenamate, 5 mg/kg s.c. & $2.8 \pm 0.5$ & & \\
Hydralazine, 1 mg/kg i.p. & $16.7 \pm 3.0^{* \mathrm{~s}}$ & $85 \pm 5^{* \mathrm{~s}}$ & $413 \pm 34$ \\
Indomethacin + hydralazine & $2.0 \pm 0.3^{* \mathrm{~h}}$ & $80 \pm 5^{* \mathrm{~s}}$ & $382 \pm 26$ \\
Meclofenamate + hydralazine & $7.4 \pm 1.5 \ddagger^{\mathrm{h}}$ & & \\
Chlorisondamine, 10 mg/kg s.c. & $5.6 \pm 0.4^{* \mathrm{~s}}$ & $63 \pm 3^{* \mathrm{~s}}$ & $289 \pm 19 \S^{\mathrm{s}}$ \\
Indomethacin + chlorisondamine & $2.1 \pm 0.4^{* \mathrm{c}}$ & $68 \pm 4^{* \mathrm{~s}}$ & $271 \pm 25 \S^{\mathrm{s}}$ \\
\hline
\end{tabular}

Each value represents the mean $\pm S E M$ for six to nine rats measured at 20 min after saline, hydralazine, or chlorosondamine administration. SRA, serum renin activity; MAP, mean arterial pressure; and HR, heart rate. s, compared with saline control; h, compared with hydralazine; c, compared with chlorisondamine; AI, angiotensin I. * $P<0.001$.

$\ddagger P<0.01$.

$\$ P<0.05$

duced renin release was inhibited by indomethacin by $100 \%(P<0.001)$. Blood pressure and heart rate remained unchanged after indomethacin alone (Table I). However, hydralazine significantly decreased mean arterial pressure by $21 \%(P<0.001)$ at $20 \mathrm{~min}$ after its administration. At this time, heart rate was not changed from control values. In the same rats pretreated with indomethacin, hydralazine produced a similar decrease in blood pressure.

Meclofenamate, another PG synthesis inhibitor (6), similarly reduced the control serum renin levels from $3.1 \pm 0.8$ to $2.8 \pm 0.5 \mathrm{ng} / \mathrm{ml}$ per $\mathrm{h}(P>0.1, \mathrm{NS})$ and inhibited hydralazine-induced renin release by $77 \%$ from $16.7 \pm 3.0$ to $7.4 \pm 1.5 \mathrm{ng} / \mathrm{ml}$ per $\mathrm{h}(P<0.01)$ (Table I).

Further examination of sympathetically mediated renin release used isoproterenol, a nonselective betaadrenergic agonist known to directly stimulate juxtaglomerular cells to release renin $(5,29,30)$. Isoproterenol caused a dose-related increase in serum renin activity, which was inhibited by $66 \%(P<0.001)$ at the $10 \mu \mathrm{g} / \mathrm{kg}$ dose and by $44 \%(P<0.05)$ at the $30 \mu \mathrm{g} / \mathrm{kg}$ dose after pretreatment with indomethacin (Fig. 1). Isoproterenol produced similar increases in heart rate and decreases in blood pressure at both the 10 and 30 $\mu \mathrm{g} / \mathrm{kg}$ doses $(P<0.001)$ (Fig. 2). However, unlike its effect on renin release, indomethacin failed to alter the fall in blood pressure or the rise in heart rate after isoproterenol.

To eliminate the systemic effects of the drug, isoproterenol was infused intraarterially, and its effect on renin release was examined (Table II). Isoproterenol increased the serum renin levels from $4.1 \pm 0.8$ to $18.7 \pm 2.7 \mathrm{ng} / \mathrm{ml}$ per $\mathrm{h}(P<0.001)$ without altering blood pressure or heart rate (Table II). Indomethacin inhibited this isoproterenol-induced renin release by $67 \%(P<0.01)$ in the absence of hemodynamic changes.

To further eliminate the involvement of hypotension in beta-adrenergically mediated renin release, the

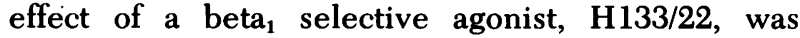
similarly tested. $\mathrm{H} 133 / 22$ increased serum renin levels from $3.1 \pm 0.4$ to $10.4 \pm 1.1(P<0.001)$ and $25.0 \pm 2.8 \mathrm{ng} / \mathrm{ml}$ per $\mathrm{h}(P<0.001)$ with 0.3 and $1 \mathrm{mg} / \mathrm{kg}$, respectively (Fig. 3). Pretreatment with indomethacin inhibited this release of renin by $80 \%$ at the $0.3 \mathrm{mg} / \mathrm{kg}$ dose and $71 \%$ at the $1 \mathrm{mg} / \mathrm{kg}$ dose. Additionally, H133/22 increased heart rate by $33 \%$ without altering blood pressure at the 0.3 and $1 \mathrm{mg} / \mathrm{kg}$ dose (Fig. 4). Similar hemodynamic changes were observed after indomethacin with the 0.3 $\mathrm{mg} / \mathrm{kg}$ dose. However, with the $1 \mathrm{mg} / \mathrm{kg}$ dose, after indomethacin, H133/22 caused a transient, 6-mm Hg decrease in blood pressure $(P<0.05)$, which was not observed in the absence of indomethacin.

To further characterize beta-adrenergically mediated renin release, an agent dibutyryl cyclic AMP was used which bypasses the juxtaglomerular beta-receptor to directly stimulate the release of renin $(32,33)$. Fig. 5 illustrates the effect of indomethacin on renin release stimulated by intraarterial infusions of dibutyryl cyclic AMP. Dibutyryl cyclic AMP increased serum renin levels from $4.1 \pm 0.2$ to $20.4 \pm 3.9 \mathrm{ng} / \mathrm{ml}$ per $\mathrm{h}(P$ $<0.001$ ), and indomethacin pretreatment inhibited renin by $96 \%$ to $4.7 \pm 1.2 \mathrm{ng} / \mathrm{ml}$ per $\mathrm{h}(P<0.001)$. The 


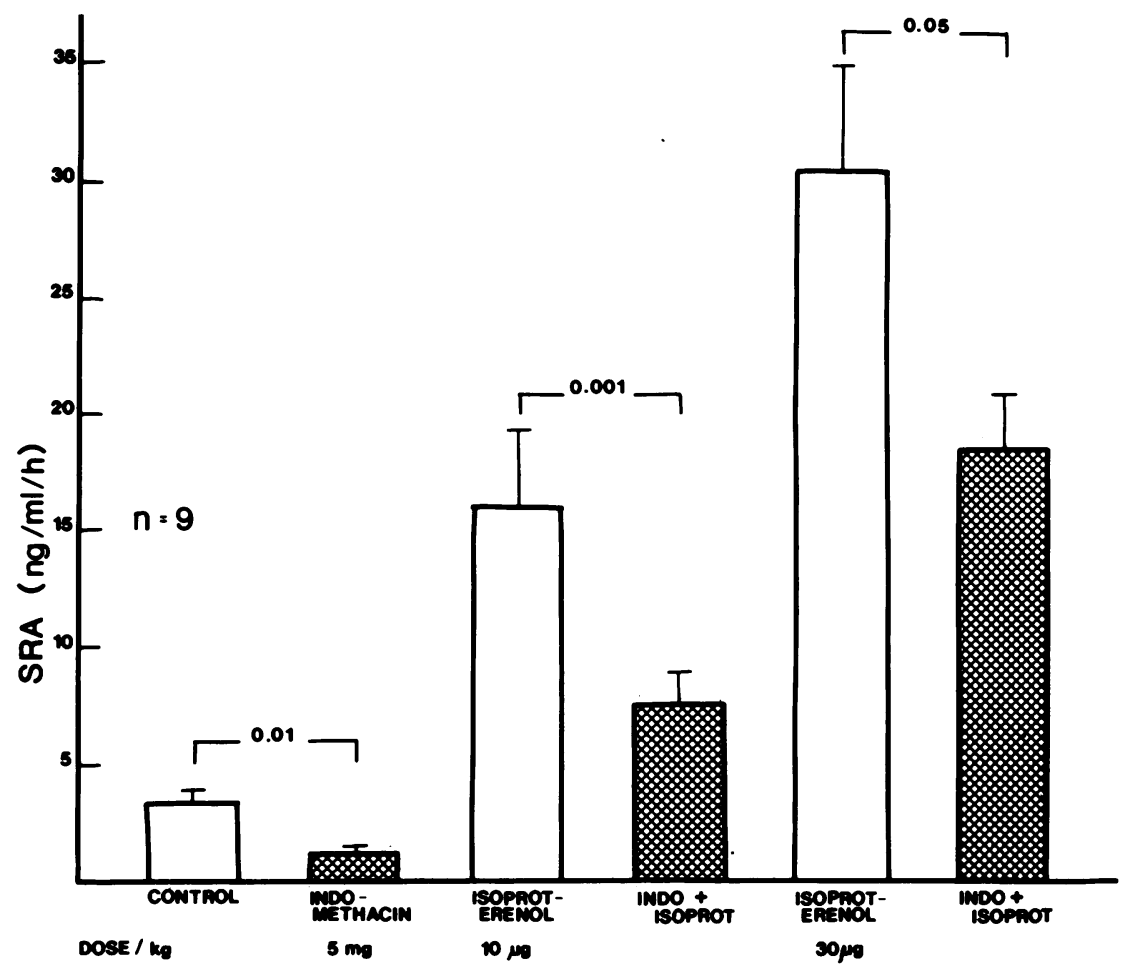

FIGURE 1 Effect of indomethacin (indo) on renin release stimulated by intraperitoneal isoproterenol (isoprot). Each point represents the mean \pm SEM for nine rats. Statistical significance is indicated by the brackets connecting the compared bars. SRA, serum renin activity.
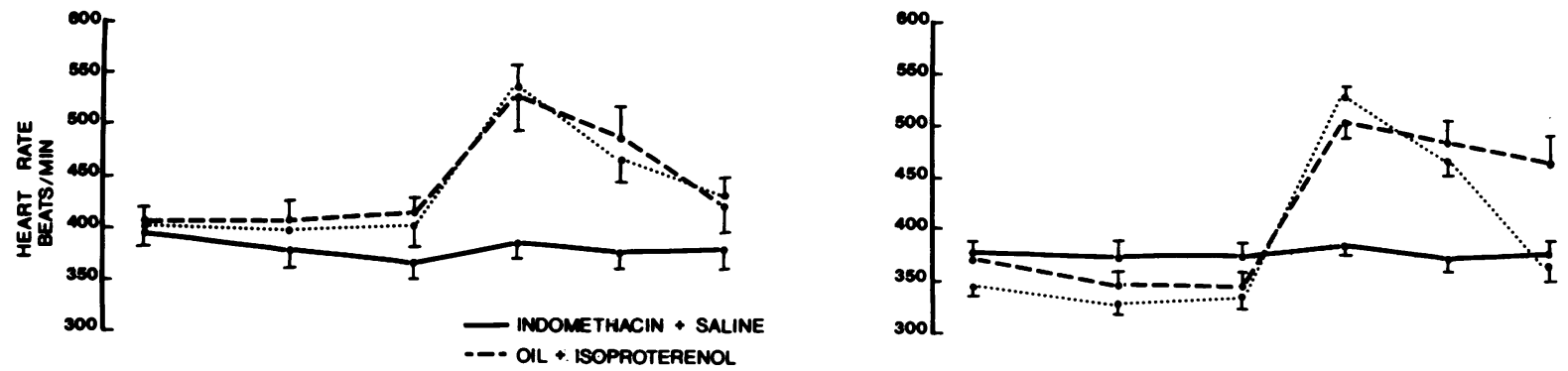

...... NDOMETHACIN + ISOPROTERENOL
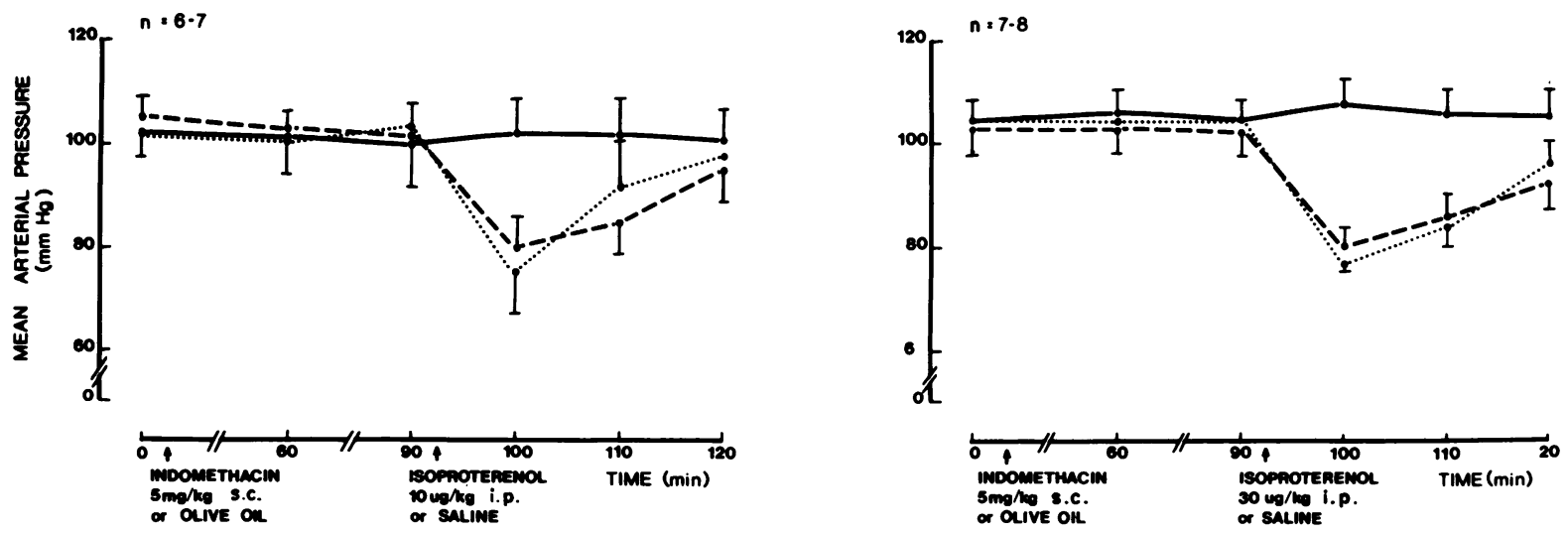

Figure 2 Effect of indomethacin on the vasodilation and tachycardia associated with the intraperitoneal administration of $10 \mu \mathrm{g} / \mathrm{kg}$ (left) and $30 \mu \mathrm{g} / \mathrm{kg}$ (right) of isoproterenol. Each point represents the mean $\pm \mathrm{SEM}$ for six to eight rats. 
TABLE II

Effect of Intraarterial Infusions of Isoproterenol on Mean Arterial Pressure, Heart Rate, and Serum Renin Activity in Conscious Rats

\begin{tabular}{lllc}
\hline \multicolumn{1}{c}{ Treatment } & MAP & \multicolumn{1}{c}{ HR } & \multicolumn{1}{c}{ SRA } \\
\hline & $m m$ Hg & beats $/$ min & ng AI/ml/h \\
Saline & $109 \pm 2$ & $385 \pm 14$ & $4.1 \pm 0.8$ \\
Indomethacin, $5 \mathrm{mg} / \mathrm{kg} \mathrm{s.c.}$ & $108 \pm 2$ & $352 \pm 8$ & $3.4 \pm 0.5$ \\
Isoproterenol, $100 \mathrm{ng} / \mathrm{kg} / \mathrm{min}$ i.a. & $111 \pm 3$ & $435 \pm 24$ & $18.7 \pm 2.7^{*}$ \\
Indomethacin + isoproterenol & $110 \pm 2$ & $412 \pm 19$ & $8.9 \pm 1.9 \ddagger$ \\
\hline
\end{tabular}

Each value represents the mean \pm SEM for six rats. Mean arterial pressure (MAP), heart rate (HR), and serum renin activity (SRA) were measured 20 min after beginning the infusion of saline or isoproterenol. AI, angiotensin I; i.a., intraarterial administration.

* $P<0.001$ compared with control.

$\ddagger P<0.01$ compared with isoproterenol.

intraarterial infusions failed to alter the blood pressure ( $109 \pm 2.5$ vs. $109 \pm 2.8 \mathrm{~mm} \mathrm{Hg}$ ); however, heart rate was increased from $338 \pm 18$ to $402 \pm 16$ beats $/ \min (P<0.05)$.

Chlorisondamine, a ganglionic blocking agent, has been found to reduce sympathetic outflow and to stimulate renin release by activation of the intrarenal baroreceptor $(29,34)$. In our studies, it lowered blood pressure from $108 \pm 3$ to $63 \pm 4 \mathrm{~mm} \mathrm{Hg}(P<0.001)$ as well as the heart rate (Table I). Similar results were obtained in the indomethacin-pretreated animals. Chlorisondamine alone significantly increased the release of renin. Indomethacin inhibited the serum renin levels in both the control and chlorisondamine-treated groups by 21 and $100 \%$, respectively $(P<0.001)$.

Finally, the effects of indomethacin and meclofenamate on the urinary excretion of $\mathrm{PGE}_{2}$ and $\mathrm{PGF}_{2 \alpha}$ were studied (Table III). Indomethacin $(5 \mathrm{mg} / \mathrm{kg})$ reduced

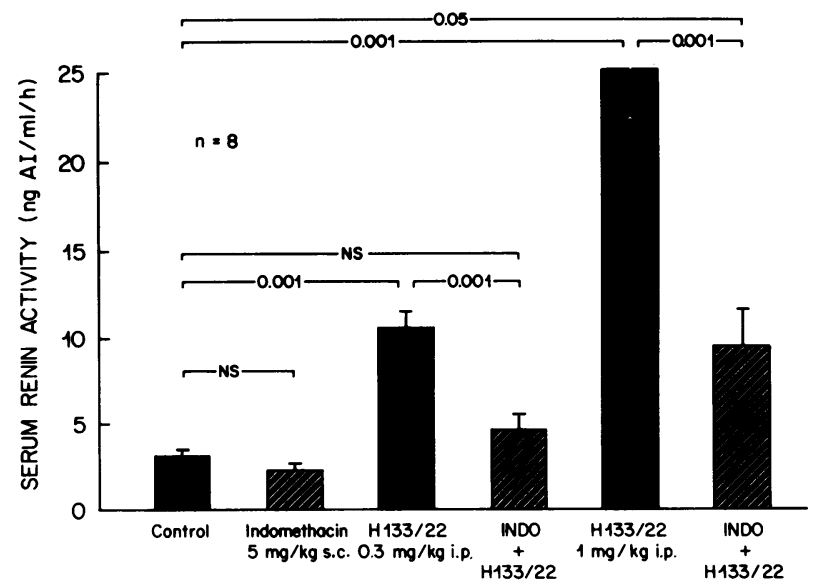

FIgURE 3 Effect of indomethacin (indo) on renin release stimulated by the beta ${ }_{1}$ selective adrenergic agonist, H133/22. Each point represents the mean \pm SEM for seven rats. Statistical significance is indicated by the brackets connecting the compared bars. AI, angiotensin I. urinary $\mathrm{PGE}_{2}$ excretion by $89 \%$ and the $\mathrm{PGF}_{2 \alpha}$ excretion by $74 \%(P<0.001)$. Meclofenamate $(5 \mathrm{mg} / \mathrm{kg})$ produced similar reductions of 68 and $65 \%$ for $\mathrm{PGE}_{2}$ and $\mathrm{PGF}_{2 \alpha}$, respectively $(P<0.001)$. Additionally, whereas in normal rats, arachidonic acid $(8 \mathrm{mg} / \mathrm{kg}$ i.v.) decreased mean arterial pressure by $28.5 \pm 3.6 \mathrm{~mm} \mathrm{Hg}$, in animals pretreated with indomethacin or meclofenemate mean arterial pressure was reduced by only $5.1 \pm 0.9$ and $4.2 \pm 1.4 \mathrm{~mm} \mathrm{Hg}(P<0.001)$, respectively.

\section{DISCUSSION}

The sympathetic nervous system, macula densa, and the intrarenal baroreceptor are the three major factors which control the release of renin (38). A number of investigators have used inhibitors of PG synthesis to probe the degree of involvement of the renal PG in these forms of renin release. In such studies, indomethacin was found to inhibit hemorrhage-induced renin release in rabbits (19). Also in dogs with a single
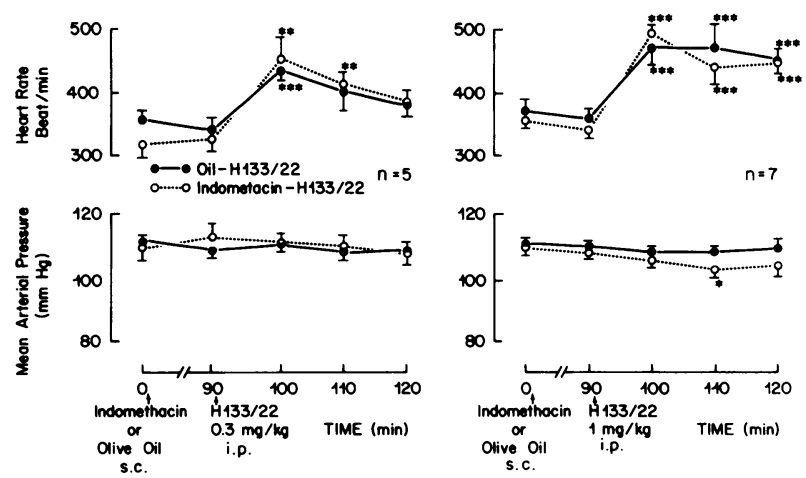

Figure 4 The effect of the beta $_{1}$ selective adrenergic agonist, $\mathrm{H} 133 / 22$, and indomethacin on blood pressure and heart rate. Each point represents the mean \pm SEM for five to seven rats. ${ }^{* * P}<0.01 ;{ }^{* * * P}<0.001$ compared with the value at $90 \mathrm{~min}$. 


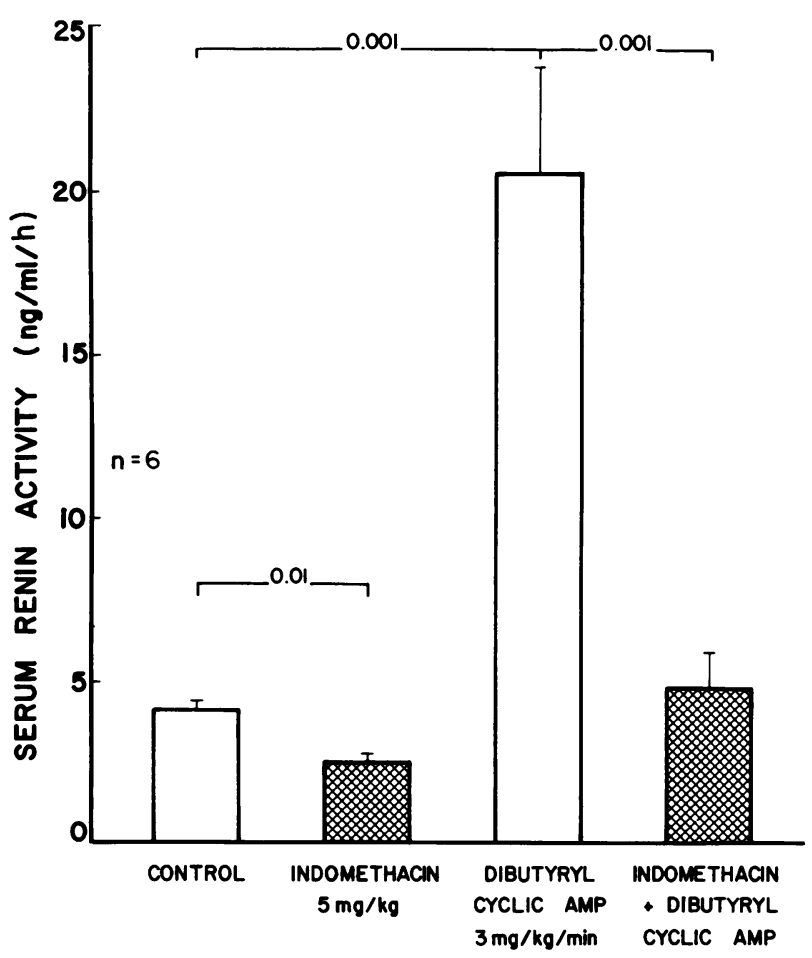

FIGURE 5 Effect of indomethacin on renin release stimulated by intraarterial infusions of dibutyryl cyclic AMP. Each point represents the mean $\pm S E M$ for six rats. Statistical differences are indicated by the brackets connecting the compared bars.

denervated, nonfiltering kidney, indomethacin blocked the renin release associated with renal arterial hypotension (39). Thus, PG are thought to participate as mediators of intrarenal baroreceptor-stimulated renin release. PG synthesis inhibitors will not, however, inhibit the renin release due to sodium depletion, which is dependent upon a macula densa mechanism $(40,41)$. Whereas PG participation in sympathetically mediated renin release has not been directly studied, indomethacin was found to inhibit several forms of renin release which were known to possess a beta-adrenergic component to their mechanism (hemorrhage, upright posture, etc.) $(16,19,23-26)$. Furthermore, renal nerve stimulation and exogenous catecholamines were found to enhance the release of PG from the kidney $(42,43)$. With this in mind, these studies were designed to examine the role of $P G$ in sympathetically mediated renin release and also to indicate the approximate site at which they may participate in this action.

The vasodilator, hydralazine, is known to stimulate renin release by reflex activation of the sympathetic nervous system $(27,28)$. In this study, the decrease in blood pressure produced by hydralazine was associated with a reflex increase in heart rate and a fivefold increase in renin release. In contrast, the ganglionic blocker, chlorisondamine, caused a decrease in blood pressure similar to that produced by hydralazine; however, because the sympathetic ganglia were blocked, there was no reflex tachycardia and only a twofold increase in renin release. This small increase in renin release by chlorisondamine was produced by the reduced blood pressure which activated the intrarenal baroreceptor (34). Thus, when the release of renin produced by hydralazine and chlorisondamine were compared, the data would indicate that the major component of the hydralazine-induced renin release is sympathetically mediated, and only a small component is baroreceptor mediated.

The PG synthetase inhibitors, indomethacin and meclofenamate, blocked this sympathetically mediated renin release produced by hydralazine without altering its effect on blood pressure. Because hydralazine has been found to decrease PG biosynthesis in rat renal medullary tissue in vitro (44), it is unlikely that the drug could directly stimulate renin release by an action on the synthesis of PG. Thus, these findings indicate that renal PG participate in sympathetically mediated renin release by an action on renal nerve activity or by a direct action on the juxtaglomerular cells.

In the rat, the role of PG in the control of norepinephrine release after sympathetic nerve stimulation is controversial. Some investigators have found that PGE inhibits the release of norepinephrine and reduces the

TABLE III

Effect of PG Synthesis Inhibitors on the Urinary Excretion of PG and Arachidonate-Induced Hypotension in the Rat

\begin{tabular}{lccc}
\hline \multicolumn{1}{c}{ Treatment } & $\mathrm{PGE}_{2}$ & $\mathrm{PGF}_{2 \alpha}$ & $\begin{array}{c}\text { Arachidonate } \\
\text { hypotension }\end{array}$ \\
\hline & $n g / 8 \mathrm{~h}$ & $n g / 8 \mathrm{~h}$ & $\mathrm{~mm} \mathrm{Hg}$ \\
Olive oil, $1 \mathrm{ml} / \mathrm{kg} \mathrm{s.c.}$ & $34.9 \pm 4.6$ & $109.0 \pm 6.2$ & $28.5 \pm 3.6$ \\
Indomethacin, $5 \mathrm{mg} / \mathrm{kg}$ s.c. & $3.8 \pm 0.7^{*}$ & $28.0 \pm 1.7^{*}$ & $5.1 \pm 0.9^{*}$ \\
Meclofenamate, $5 \mathrm{mg} / \mathrm{kg}$ s.c. & $11.2 \pm 4.4^{*}$ & $38.3 \pm 7.9^{*}$ & $4.2 \pm 1.4^{*}$ \\
\hline
\end{tabular}

Each value represents the mean \pm SEM for six rats.

* $P<0.001$ compared with control. 


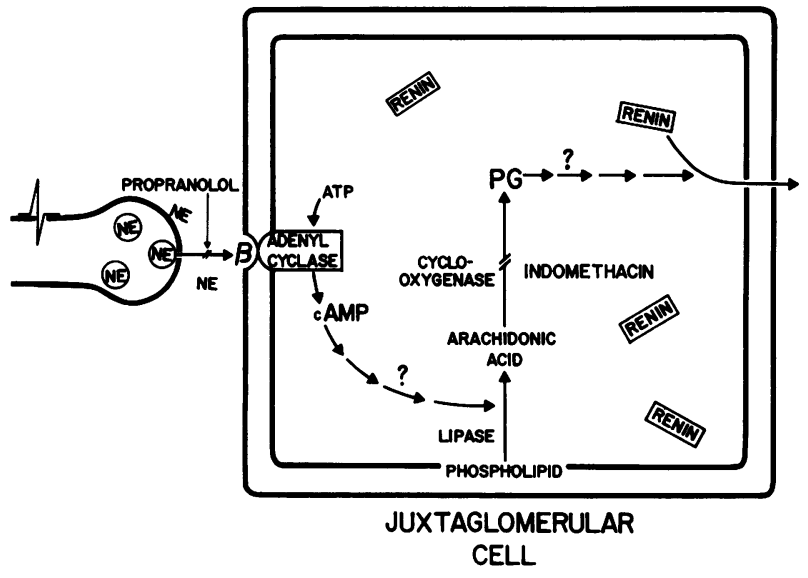

FIgURE 6 A schematic representation of the role of PG in sympathetically mediated renin release. $\mathrm{NE}$, norepinephrine; cAMP, cyclic AMP; $\beta$, beta-receptor.

vasoconstrictor responses to nerve stimulation and that indomethacin, by removing this tonic inhibitory influence, enhances these effects (45-48). In contrast, Malik and McGiff (49) reported that PGE enhanced the vasoconstrictor effects of sympathetic nerve stimulation and exogenous norepinephrine in the rat mesentery and suggested that in the rat, unlike other species, PG facilitate norepinephrine release. However, subsequent studies have indicated that PGE inhibits the release of norepinephrine after nerve stimulation in the rat mesentery and enhances the vasoconstrictor responses via a postsynaptic effect. ${ }^{2}$ Thus, indomethacin in our studies should enhance the release of norepinephrine after sympathetic activation by hydralazine. This increased norepinephrine release should increase rather than decrease the release of renin unless indomethacin had an additional postsynaptic effect to block the release of renin at or distal to the juxtaglomerular betaadrenergic receptor (Fig. 6).

With these possibilities in mind, isoproterenol, a beta-adrenergic agonist, was used to directly stimulate juxtaglomerular beta receptors, thus bypassing the renal nerves. As with hydralazine, indomethacin inhibited isoproterenol-induced renin release without altering the associated hypotension or tachycardia. Thus, because classical beta-adrenergic blocking drugs inhibit not only the release of renin but also the tachycardia and hypotension caused by the beta-adrenergic agonist $(50,51)$, it would appear unlikely that indomethacin is inhibiting renin release via blockade of beta-adrenergic receptors. Along these lines, Frolich et al. (52) also found that indomethacin could inhibit isoproterenol-induced renin release in normal subjects. These findings suggest that renal PG exert their

${ }^{2}$ Malik, K. U. Personal communication. action on sympathetically mediated renin release at a point in the juxtaglomerular cell distal to the betaadrenergic receptor (Fig. 6).

Because the systemic administration of isoproterenol was associated with a profound hypotension, the possibility must be considered that the enhanced rate of renin release after isoproterenol was the result of not only juxtaglomerular cell beta-receptor activation but also baroreceptor activation. To eliminate the baroreceptor contribution to renin release, two types of experiments were performed: $(a)$ isoproterenol was infused intraarterially in conscious rats in doses which stimulated the release of renin without altering systemic blood pressure, and $(b)$ a selective beta ${ }_{1}$-adrenergic agonist, H133/22, (31) was used which released renin and increased heart rate through activation of beta $_{1}$ receptors yet failed to activate the beta ${ }_{2}$ receptors necessary for hypotension. In the absence of hypotension, indomethacin pretreatment inhibited these two types of renin release, again suggesting a role for renal PG in sympathetically mediated renin release.

This contention was further examined by testing the effect of indomethacin on dibutyryl cyclic AMP-stimulated renin release. Because this agent does not reduce arterial blood pressure but stimulates renin release in vivo and in vitro by a mechanism which is not inhibited by propranolol $(32,33)$, it is thought to increase the release of renin by a direct action on juxtaglomerular cells. Indomethacin also inhibited dibutyryl cyclic AMP-stimulated renin release, which further suggested that PG mediated the sympathetically induced renin release via an action past the betaadrenergic receptor (Fig. 6). Along these lines, Lindgren et al. (53) reported that dibutyryl cyclic AMP increased the release of arachidonic acid and the formation of PG in cultured 3T3 fibroblasts.

In these studies, indomethacin inhibited several forms of sympathetically mediated renin release. This inhibitory effect of the drug seems to be related to its ability to inhibit PG synthesis because a similar effect was observed with meclofenamate, a structurally dissimilar PG synthesis inhibitor, and because in the doses used both compounds markedly inhibited the urinary excretion of $\mathrm{PGE}_{2}$ and $\mathrm{PGF}_{2 \alpha}$ and arachidonateinduced hypotension. Thus, these data indicate that renal PG play an important role in sympathetically mediated renin release in the rat and act at a site distal to the beta-adrenergic receptor of the juxtaglomerular cell (Fig. 6).

\section{ACKNOWLEDGMENTS}

The authors express their appreciation to Ms. Beverley Adams and Ms. Judy Zimmer for their technical assistance and Mrs. Stephanie Wooten for her secretarial assistance. They also thank Dr. Knud Poulsen for the gift of the angiotensin I anti- 
sera and Dr. J. E. Pike of The Upjohn Co. for the prostaglandins.

Support was provided by grants from the National Heart, Lung, and Blood Institute (HL 21066) and the Texas Heart Association.

\section{REFERENCES}

1. Larsson, C., P. Weber, and E. Anggard. 1974. Arachidonic acid increases and indomethacin decreases plasma renin activity in the rabbit. Eur. J. Pharmacol. 28: 391-394.

2. Weber, P., H. Holzgreve, R. Stephan, and R. Herbst. 1975. Plasma renin activity and renal sodium and water excretion following infusion of arachidonic acid in rats. Eur. J. Pharmacol. 34: 299-304.

3. Bolger, P. M., G. M. Eisner, P. W. Ramwell, and L. M. Slotkoff. 1976. Effect of prostaglandin synthesis on renal function and renin in the dog. Nature (Lond.). 259: 244245.

4. Weber, P. C., C. Larsson, E. Anggard, M. Hamberg, E. J. Corey, K. C. Nicolaou, and B. Samuelsson. 1976. Stimulation of renin release from rabbit renal cortex by arachidonic acid and prostaglandin endoperoxides. Circ. Res. 39: 868-874.

5. Whorton, A. R., K. Misono, J. Hollifield, J. C. Frolich, T. Inagami, and J. A. Oates. 1977. Prostaglandins and renin release. I. Stimulation of renin release from rabbit renal cortical slices by $\mathrm{PGI}_{2}$. Prostaglandins. 14: 10951105.

6. Flower, R. J. 1974. Drugs which inhibit prostaglandin biosynthesis. Pharmacol. Rev. 26: 33-67.

7. Werning, C., W. Vetter, P. Weidmann, H. U. Schweikert, D. Stiel, and W. Siegenthaler. 1971. Effect of prostaglandin $\mathrm{E}_{1}$ on renin in the dog. Am. J. Physiol. 220: 852856.

8. Yun, J., G. Kelly, F. C. Bartter, and H. Smith, Jr. 1977. Role of prostaglandins in the control of renin secretion in the dog. Circ. Res. 40: 459-464.

9. Bolger, P. M., G. M. Eisner, P. T. Shea, P. W. Ramwell, and L. M. Slotkoff. 1977. Effects of $\mathrm{PGD}_{2}$ on canine renal function. Nature (Lond.). 267: 628-630.

10. Bolger, P. M., G. M. Eisner, P. W. Ramwell, and L. M. Slotkoff. 1978. Renal actions of prostacyclin. Nature (Lond.). 271: 467-469.

11. Gerber, J. G., R. A. Branch, A. S. Nies, J. F. Gerkens, D. G. Shand, J. Hollifield, and J. A. Oates. 1978. Prostaglandins and renin release. II. Assessment of renin secretion following infusion of $\mathrm{PGI}_{2}, \mathrm{E}_{2}$ and $\mathrm{D}_{2}$ into the renal artery of anesthetized dogs. Prostaglandins. 15: 81-89.

12. Krakoff, L. R., D. DeGuia, N. Vlachakis, J. Stricker, and M. Goldstein. 1973. Effect of sodium balance on arterial blood pressure and renal responses to prostaglandin $A_{1}$ in man. Circ. Res. 33: 539-546.

13. Golub, M. S., P. F. Speckart, P. K. Zia, and R. Horton. 1976. The effect of prostaglandin $A_{1}$ on renin and aldosterone in man. Circ. Res. 39: 574-579.

14. Zenser, T. V., C. A. Herman, R. R. Gorman, and B. B. Davis. 1977. Metabolism and action of the prostaglandin endoperoxide $\mathrm{PGH}_{2}$ in rat kidney. Biochem. Biophys. Res. Commun. 79: 357-363.

15. Whorton, A. R., M. Smigel, J. A. Oates, and J. C. Frolich. 1978. Regional differences in prostacyclin formation by the kidney-prostacyclin is a major prostaglandin of renal cortex. Biochim. Biophys. Acta. 529: 176-180.

16. Rumpf, K. W., S. Frenzel, H. D. Lowitz, and F. Scheler. 1975. The effect of indomethacin on plasma renin activity in man under normal conditions and after stimulation of the renin angiotensin system. Prostaglandins. 10: 641648.

17. Patak, R. V., B. K. Mookerjee, C. J. Bentzel, P. E. Hysert, M. Babej, and J. B. Lee. 1975. Antagonism of the effects of furosemide by indomethacin in normal and hypertensive man. Prostaglandins. 10: 649-659.

18. Frolich, J. C., J. W. Hollifield, J. C. Dormois, B. L. Frolich, H. Seyberth, A. M. Michelakis, and J. A. Oates. 1976. Suppression of plasma renin activity by indomethacin in man. Circ. Res. 39: 447-452.

19. Romero, J. C., C. L. Dunlap, and C. G. Strong. 1976. The effect of indomethacin and other anti-inflammatory drugs on the renin-angiotensin system. J. Clin. Invest. 58: 282288.

20. Fichman, M. P., N. Telfer, P. Zia, P. Speckart, M. Golub, and R. Rude. 1976. Role of prostaglandins in the pathogenesis of Bartter's syndrome. Am. J. Med. 60: 785-797.

21. Gill, J. R., J. C. Frolich, R. E. Bowden, A. A. Taylor, H. R. Keiser, H. W. Seyberth, J. A. Oates, and F. C. Bartter. 1976. Bartter's syndrome: a disorder characterized by high urinary prostaglandins and a dependence of hyperrenmenia on prostaglandin synthesis. Am. J. Med. 61: 43-51.

22. Torres, V. E., C. G. Strong, J. C. Romero, and D. M. Wilson. 1975. Indomethacin enhancement of glycerolinduced acute renal failure in rabbits. Kidney Int. 7: 170178.

23. Romero, J. C., and C. G. Strong. 1977. The effect of indomethacin blockade of prostaglandin synthesis on blood pressure of normal rabbits and rabbits with renovascular hypertension. Circ. Res. 40: 35-41.

24. Tobert, J. A., J. D. H. Slater, F. Fogelman, S. L. Lightman, A. B. Kurtz, and N. N. Payne. 1973. The effect in man of (+)-propranolol on renin secretion stimulated by orthostatic stress. Clin. Sci. (Oxf.). 44: 291-295.

25. Michelakis, A. M., and R. G. McAllister. 1972. The effect of chronic adrenergic receptor blockade on plasma renin activity in man. J. Clin. Endocrinol. Metab. 34: 386-394.

26. Winer, N. 1972. Mechanism of increased renin secretion associated with adrenalectomy, hemorrhage, renal artery constriction, and sodium depletion. In Hypertension 72. J. Genest and E. Koiw, editors. Springer-Verlag New York, Inc., New York. 25-36.

27. Pettinger, W. A., W. B. Campbell, and K. Keeton. 1973. Adrenergic component of renin release induced by vasodilating antihypertensive drugs in the rat. Circ. Res. 33: 82-86.

28. Pettinger, W. A., and K. Keeton. 1975. Altered renin release and propranolol potentiation of vasodilatory drug hypotension. J. Clin. Invest. 55: 236-243.

29. Pettinger, W. A., L. Augusto, and A. S. Leon. 1972. Alteration of renin release by stress and adrenergic receptor and related drugs in unanesthetized rats. In Comparative Pathophysiology of Circulatory Disturbances. C. M. Bloor, editor. Plenum Publishing Corp., New York. 105117.

30. Weinberger, M. H., W. Aoi, and D. P. Henry. 1975. Direct effect of beta-adrenergic stimulation on renin release by the rat kidney slice in vitro. Circ. Res. 37: 318-324.

31. Carlsson, E., C-G. Dahlof, A. Hedberg, H. Persson, and B. Tangstrand. 1977. Differentiation of cardiac chrontropic and inotropic effects of $\beta$-adrenoceptor agonists. Naunyn-Schmiedeberg's Arch Pharmacol. 300: 101-105.

32. Michelakis, A. M., J. Caudle, and G. W. Liddle. 1969. In vitro stimulation of renin production by epinephrine, norepinephrine, and cyclic AMP. Proc. Soc. Exp. Biol. Med. 130: 748-753.

33. Okahara, T., Y. Abe, and K. Yamamoto. 1977. Effects of 
dibutyryl cyclic AMP and propranolol on renin secretion in dogs. Proc. Soc. Exp. Biol. Med. 156: 213-218.

34. Keeton, T. K., and W. A. Pettinger. 1979. The dominance of adrenergic mechanism in mediating hypotensive druginduced renin release in the conscious rat. J. Pharmacol. Exp. Ther. 208: 303-309.

35. Weeks, J. R. 1973. Upjohn 1011. Available upon request from Dr. Weeks, Upjohn Co., Kalamazoo, Mich.

36. Poulsen, K., and J. Jorgensen. 1974. An easy radioimmunological microassay of renin activity, concentration, and substrate in human and animal plasma and tissue based on angiotensin I trapping by antibody. J. Clin. Endocrinol. Metab. 39: 816-825.

37. Dray, F., B. Charbonner, and J. Maclouf. 1975. Radioimmunoassay of prostaglandins $F \alpha, E_{1}$, and $E_{2}$ in human plasma. Eur. J. Clin. Invest. 5: 311-318.

38. Davis, J. O., and R. H. Freeman. 1976. Mechanisms regulating renin release. Physiol. Rev. 56: 1-56.

39. Data, J. L., H. G. Gerber, W. J. Crump, J. C. Frolich, J. W. Hollifield, and A. S. Nies. 1978. The prostaglandin system. A role in canine baroreceptor control of renin release. Circ. Res. 42: 454-458.

40. Campbell, W. B., E. K. Jackson, and R. M. Graham. 1979. Saralasin-induced renin release: blockade by prostaglandin synthetase inhibitors. Hypertension. In press.

41. Norbiato, G., M. Bevilacqua, U. Raggi, P. Micossi, C. Moroni, and A. Fasoli. 1978. Effect of prostaglandin synthetase inhibitors on renin and aldosterone in man on a normal or low sodium diet. Acta Endocrinol. 87: 577-588.

42. Dunham, E. W., and B. G. Zimmerman. 1970. Release of prostaglandin-like material from dog kidney during nerve stimulation. Am. J. Physiol. 219: 1279-1285.

43. Needleman, P., J. R. Douglas, Jr., B. Jakschik, P. B. Stoecklein, and E. M. Johnson, Jr. 1974. Release of renal prostaglandin by catecholamines: relationship to renal endocrine function.J. Pharmacol. Exp. Ther. 188: 453-460.

44. Taube, C., H. J. Mest, H. U. Block, and W. Forster. 1976. Changes in prostaglandin synthesis in rabbit kidney medulla after repeated intravenous administration of antihypertensive drugs. Artery. 2: 564-573.

45. Bergstrom, S., L-O. Farnebo, and K. Fuxe. 1973. Effect of prostaglandin $\mathrm{E}_{2}$ on central and peripheral catecholamine neurons. Eur. J. Pharmacol. 21: 362-368.

46. Needleman, P., G. R. Marshall, and E. M. Johnson. 1974. Determinants and modification of adrenergic and vascular resistance in the kidney. Am. J. Physiol. 3: 665-669.

47. Fredholm, B. B., and P. Hedqvist. 1975. Indomethacininduced increase in noradrenaline turnover in some rat organs. Br. J. Pharmacol. 54: 295-300.

48. Jackson, E. K., W. B. Campbell, and W. G. Clark. 1979. Inhibition of angiotensin II enhancement of adrenergic transmission by propranolol: an antihypertensive mechanism. Fed. Proc. 38: 678. (Abstr.)

49. Malik, K. U., and J. C. McGiff. 1975. Modulation by prostaglandins of adrenergic transmission in the isolated perfused rabbit and rat kidney. Circ. Res. 36: 599-609.

50. Weber, M. A., I. R. Thornell, and G. S. Stokes. 1974. Effects of beta adrenergic blocking agents on plasma renin activity in the conscious rabbit. J. Pharmacol. Exp. Ther. 188: 234-240.

51. Harms, H. H., L. Gooren, A. J. G. Spoelstra, C. Hesse, and L. Verschoor. 1978. Blockade of isoprenaline-induced changes in plasma free fatty acids, immunoreactivity insulin levels and plasma renin activity in healthy human subject, by propranolol, pindolol, practolol, atenolol, metoprolol and acebutolol. Br. J. Clin. Pharmacol. 5: 19-26.

52. Frolich, J. C., J. W. Hollifield, and J. A. Oates. 1976. Effect of indomethacin on isoproterenol induced renin release. Clin. Res. 24: 9A. (Abstr.)

53. Lindgren, J. A., A-E. Claesson, and S. Hammarstrom. 1978. Stimulation of arachidonic acid release and prostaglandin production in $3 \mathrm{~T} 3$ fibroblasts by adenosine $3^{\prime}: 5^{\prime}$ monophosphate. Adv. Prostaglandin Thromboxane Res. 3: $167-174$ 